\title{
PENGGUNAAN SAPAAN KEKERABATAN BAHASA ACEH DALAM TUTURAN MASYARAKAT KABUPATEN ACEH UTARA
}

\author{
oleh \\ Mursyidah, Safriandi*, Trisfayani \\ "Dosen Program Studi Pendidikan Bahasa Indonesia, FT Universitas Malikussaleh \\ surel: safriandi_pbi@unimal.ac.id
}

\begin{abstract}
ABSTRAK
Penelitian ini bertujuan untuk mendeskripsikan (1) bentuk sapaan kekerabatan bahasa Aceh dalam tuturan masyarakat Kabupaten Aceh Utara dan (2) penggunaan sapaan kekerabatan bahasa Aceh dalam tuturan masyarakat Kabupaten Aceh Utara. Pendekatan penelitian ini adalah pendekatan kualitatif dengan jenis penelitian deskriptif. Data penelitian ini adalah tuturan masyarakat yang mengandung bentuk dan penggunaan sapaan kekerabatan bahasa Aceh. Sumber data penelitian ini adalah masyarakat di Kecamatan Samudera dan Kecamatan Meurah Mulia, Kabupaten Aceh Utara. Peneliti memilih dua gampong di masing-masing kecamatan, yaitu Gampong Tanjong Baroh dan Madan di Kecamatan Samudera, Gampong Baroh Kuta Batee dan Menjee Payong di Kecamatan Meurah Mulia. Data dikumpulkan dengan teknik sampling, yaitu nonprobability sampling jenis sampling purposive. Pengumpulan data menggunakan metode simak dengan teknik sadap dan simak libat cakap dan metode cakap dengan teknik catat. Hasil penelitian menunjukkan bahwa (1) sapaan kekerabatan bahasa Aceh dikelompokkan menjadi bentuk kata sapaan kekerabatan berdasarkan garis keturunan dan bentuk kata sapaan berdasarkan hubungan perkawinan dan (2) penggunaan sapaan kekerabatan bahasa Aceh berdasarkan garis keturunan sebanyak 21 penggunaan dan penggunaan sapaan kekerabatan bahasa Aceh berdasarkan hubungan perkawinan sebanyak 24 penggunaan.
\end{abstract}

Kata Kunci: bahasa Aceh, bentuk kata sapa, kata sapaan kekerabatan 


\section{PENDAHULUAN}

Penelitian ini mengkaji (1) bentuk sapaan kekerabatan bahasa Aceh dalam tuturan masyarakat Kabupaten Aceh Utara dan (2) penggunaan sapaan kekerabatan, baik kekerabatan secara keturunan (pertalian darah) dan karena hubungan perkawinan pada penggunaan sapaan kekerabatan bahasa Aceh dalam tuturan masyarakat Kabupaten Aceh Utara. Kata sapaan digunakan untuk menyapa, menegur, menyebut orang kedua atau orang yang diajak berbicara. Kata sapaan adalah kata-kata yang dipergunakan untuk menyapa, menegur atau menyebut orang kedua atau orang yang diajak bicara (Chaer dalam Irawan, 2019). Penggunaan sapaan dalam komunikasi dapat dipengaruhi oleh beberapa hal, seperti siapa yang menyapa, siapa yang disapa, dan hubungan antara pembicara. Kata sapaan untuk bertegur sapa tidak selalu sama untuk setiap lawan bicara. Di sisi lain, penggunaan kata sapaan yang berbeda ini dipengaruhi oleh hubungan antara penyapa dan disapa. Hubungan yang dimaksud adalah hubungan kekerabatan atau nonkekerabatan.

Setiap daerah memiliki sistem sapaan kekerabatan yang berbeda-beda. Masyarakat di Kecamatan Samudera dan Meurah Mulia sangat mengenal istilah kata sapaan dalam bertutur sapa, baik dalam kekerabatan maupun diluar kekerabatan. Bentuk sapaan yang digunakan masyarakat Kecamatan Samudera dan Meurah Mulia, Kabupaten Aceh Utara, Provinsi Aceh merupakan keunikan berbahasa yang menarik untuk dikaji. Keunikan sapaan dapat dilihat dari pemakaiannya yang berdasarkan pada hubungan kekerabatan yang dimiliki. Alasan dilakukannya penelitian ini adalah sebagai berikut. Pertama, peneliti tertarik meneliti terkait penggunaan sapaan kekerabatan bahasa Aceh karena bentuk sapaan yang digunakan masyarakat Kabupaten Aceh Utara memiliki kevariasian untuk diteliti, tepatnya sapaan antarkeluarga atau kekerabatan seperti yang diuraikan sebelumnya.

(1) Peugah bak aduen, lôn hana lôn jak uroe nyoe!

'Katakan pada aduen, saya tidak pergi hari ini!'

(2) Na Abu si Nur i rumoh?

'Ada Abu si Nur di rumah?'

Pada peristiwa tutur di atas, kata sapaan Aduen digunakan oleh seorang adik untuk menyapa kakak laki-laki/abang. Sebaliknya, jika seorang kakak lakilaki/abang menyapa adik menggunakan bentuk sapaan yang lain. Pada tuturan selanjutnya, bentuk sapaan $A b u$ merupakan kata sapaan yang digunakan seorang anak untuk menyapa ayahnya. Sapaan Abu si Nur merupakan salah satu bentuk sapaan yang digunakan seorang istri untuk menyapa suaminya.

Kedua, kevariasian penggunaan bentuk sapaan masyarakat Kabupaten Aceh Utara dapat menjadi keunikan dan mempunyai nilai tersendiri bagi perkembangan bahasa Aceh di wilayah Kabupaten Aceh Utara. Ketiga, penggunaan sapaan kekerabatan tersebut yang semakin jarang. Akibatnya, keberadaan sapaan asli bahasa Aceh dalam tuturan masyarakat Kabupaten Aceh Utara khususnya di Kecamatan Samudera dan Meurah Mulia mulai tergantikan atau tergeserkan oleh kata penyapa dalam bahasa Indonesia. Mereka lebih sering dan terbiasa menggunakan bentuk sapaan luar yang bukan kata sapaan bahasa Aceh asli. Bentuk sapaan tersebut, seperti om, tante, paman, mami, dan lain sebagainya. Oleh karena itu, peneliti perlu meneliti penggunaan sapaan kekerabatan bahasa Aceh dalam tuturan masyarakat Kabupaten Aceh Utara agar menghindari kepunahan dan penggeseran penggunaan sapaan kekerabatan. Alasan lain peneliti meneliti penggunaan sapaan kekerabatan bahasa Aceh dalam tuturan masyarakat di kedua kecamatan tersebut ialah untuk mengetahui bentukbentuk penggunaan sapaan bahasa Aceh asli yang sudah jarang digunakan masyarakat.

\section{LANDASAN TEORI}

Sapaan merupakan bentuk kata yang digunakan dalam kegiatan sapa-menyapa. Kartomiharjo (dalam Rusbiyantoro, 2011:60) menyatakan bahwa sapaan merupakan salah satu komponen bahasa yang penting karena dalam sapaan itu dapat ditentukan suatu interaksi tertentu akan berlanjut. Kata sapaan dipakai untuk menegur, memanggil, dan menyebut lawan bicara dalam pertuturan. Adapun para pelaku yang disebut ialah pembicara, lawan bicara, serta orang yang sedang dibicarakan. Menurut Subhayni, dkk. dalam penelitianya berjudul Rekontruksi Sapaan Kekerabatan Bahasa Aceh sebagai 
Pendidikan Strategi Tutur Sapa bagi Kaum Muda Aceh (2020:126) menyatakan bahwa lawan bicara diklasifikasikan menjadi lima jenis, yakni ego terhadap urutan kelahiran dalam keluarga, ego terhadap lawan bicara yang lebih tua, ego terhadap lawan bicara yang lebih muda, ego terhadap lawan bicara yang sebaya, dan ego terhadap lawan bicara menurut jenis kelamin.

Pengertian kata sapaan juga disampaikan oleh beberapa ahli. Kridalaksana (dalam Sari dkk. 2013:512) mengemukakan bahwa kata sapaan adalah morfem, kata, atau frase yang dipergunakan untuk saling merujuk dalam situasi pembicaraan yang berbeda-beda menurut sifat hubungan antara pembicara itu. Lebih lanjut, Brown dan Gilman (dalam Relawati 2012:9) juga menyampaikan bahwa kata sapaan merujuk pada kata ganti yang digunakan untuk menyapa orang kedua. Pemilihan kata ganti orang kedua yang digunakan pembicara kepada lawan bicara dipengaruhi oleh dua faktor, yakni kekuasaan (power) dan solidaritas (solidarity). Selain itu, Riegel (dalam Maulida, 2015:21) menerangkan bahwa kata sapaan dalam bahasa Prancis ada tiga ketegori, yaitu (1) un nom proper (nama diri), (2) les nom communs (nomina umum), dan (3) le pronom personnel (pronomina persona).

Bentuk sapaan merupakan bentuk kebahasaan yang di dalamnya dikenal adanya tingkatan penggunaan sapaan. Braun (dalam Subhayni, dkk. 2020:119) menjelaskan bahwa sistem sapaan (the system of address) terdiri dari keseluruhan bentuk beserta hubungan antara bentuk-bentuk itu di dalam suatu bahasa. Bentuk sapaan yang digunakan oleh pemakai bahasa dalam komunikasi lisan berkaitan erat dengan sistem kata ganti orang yaitu kata sapaan. Bentuk kata sapaan dibagi menjadi bentuk kata sapaan kekerabatan langsung dan kekerabatan tidak langsung (Saputra dan Amral, 2020:83). Menurut Subhayni dkk. (2020:125-126) bentuk sapaan dalam bahasa Aceh dibedakan menjadi dua, yaitu kata sapaan berdasarkan garis keturunan dan kata sapaan berdasarkan garis perkawinan. Selain pendapat-pendapat di atas, berdasarkan penelitian yang telah dilakukan Jannah, dkk. (2019:148) data tentang penggunaan sapaan kekerabatan yang telah diperoleh dikelompokkan berdasarkan garis keturunan, hubungan perkawinan, dan hubungan peran.

Kekerabatan adalah unit-unit sosial yang terdiri atas beberapa keluarga yang memiliki hubungan darah atau hubungan perkawinan. Dalam Depdikmas (2016:548) kata kerabat berarti yang dekat; keluarga (pertalian keluarga); sedarah sedaging; sanak saudara; dan keturunan dari induk yang sama yang dihasilkan dari gamet yang berbeda. Mahmud (dalam Irawan, 2019:97) menyatakan bahwa kekerabatan merupakan suatu bentuk hubungan sosial yang terjadi karena keturunan (consanguinity) dan perkawinan (affinity). Menurut Depdikmas (2016:837) patrilineal adalah istilah yang berkenaan dengan hubungan keturunan melalui garis kerabat lelaki saja. Matrilineal adalah suatu adat masyarakat yang mengatur alur keturunan berasal dari ibu.

Penggunaan sapaan dalam komunikasi dipengaruhi oleh beberapa faktor, baik faktor sosial maupun situasional. Arso (dalam Saleh, 2017:21) menyatakan bahwa terdapat beberapa jenis kata sapaan yang dipengaruhi oleh faktor lingkungan, umur, status, dan keakraban. Suhardi (dalam Maulida, 2015:26) menyebutkan bahwa terdapat beberapa faktor yang mempengaruhi penggunaan kata sapaan, yaitu sebagai berikut: (a) usia, (b) situasi, (c) etnik, (d) keakraban, (e) status sosial, (f) jenis kelamin, (g) keakraban, (h) status pernikahan, dan (asal).

\section{METODE PENELITIAN}

Pendekatan dalam penelitian ini adalah pendekatan kualitatif. Penelitian kualitatif merupakan metode yang digunakan untuk meneliti kondisi objek yang alamiah sebagai lawannya eksperimen. Pendekatan ini dipilih karena penelitian yang menggunakan penelitian kualitatif bertujuan untuk memahami objek yang diteliti secara mendalam pada latar yang alamiah (naturalistik). Tujuan penelitian ini yaitu untuk mendeskripsikan penggunaan sapaan kekerabatan bahasa Aceh dalam tuturan masyarakat Kabupaten Aceh Utara. Adapun jenis penelitian yang digunakan dalam penelitian ini adalah jenis penelitian deskriptif. Muhammad (2014:33-34) mendefenisikan deskriptif adalah sifat data penelitian kualitatif. Jenis penelitian ini dipilih 
karena tujuan dari penelitian deskriptif dalam metode ini ialah untuk mendeskripsikan, menganalis, dan menjelaskan fenomena kebahasaan yang sedang diteliti, fokusnya pada penggunaan sapaan kekerabatan bahasa Aceh dalam tuturan masyarakat Kabupaten Aceh Utara.

Data penelitian ini adalah tuturan masyarakat berupa kalimat yang mengandung sapaan kekerabatan bahasa Aceh. Adapun sumber data penelitian ini adalah masyarakat di Kecamatan Samudera dan Kecamatan Meurah Mulia, Kabupaten Aceh Utara. Sumber data dalam penelitian ini ditentukan dengan menggunakan teknik sampling, yakni Nonprobability Sampling jenis Sampling Purposive. Alasan teknik ini dipilih karena penelitian ini berkenaan tentang penggunaan sapaan kekerabatan bahasa Aceh dalam tuturan masyarakat. Jadi, sampel sumber datanya adalah orang-orang yang memakai sapaan tersebut dan paham dalam pengunaan sapaan kekerabatan bahasa Aceh. Adapun persyaratan-persyaratan untuk menjadi seorang sumber data menurut Mahsun (2017:142) di antaranya adalah sebagai berikut: (a) berjenis kelamin pria atau wanita, (b) berusia antara 25-65 tahun (tidak pikun), (c) orang tua, istri, atau suami informan lahir dan dibesarkan di desa itu serta jarang atau tidak pernah meninggalkan desanya, dan (d) berpendidikan maksimal tamat pendidikan dasar (SD-SMP).

Data penelitian ini dikumpulkan dengan metode simak dan metode cakap. Dalam melaksanakan metode simak, peneliti menyimak setiap tuturan yang dituturkan oleh subjek. Teknik dasar yang digunakan adalah teknik sadap, kemudian dilanjutkan dengan teknik simak libat cakap. Dalam melaksanakan metode cakap, teknik pancing merupakan teknik dasar dalam metode cakap, kemudian teknik lanjutannya yaitu teknik cakap semuka dan teknik cakap tansemuka. Dalam metode cakap peneliti juga menggunakan teknik catat untuk memudahkan peneliti mengelompokkan data. Teknik rekam juga dilakukan peneliti agar data dapat diawetkan untuk ditranskrip baik secara fonetik, fonemis, maupun ortografis.

Penelitian ini dianalisis menggunakan metode deskriptif yang bertujuan untuk mendeskripsikan penggunaan sapaan kekerabatan bahasa Aceh dalam tuturan mayarakat Kabupaten Aceh Utara. Adapun langkah-langkah ananisis data pada penelitian itu, yaitu (a) pengunpulan data, (b) reduksi data, (c) penyajian data, dan (d) verifikasi dan penerikan kesimpulan.

\section{HASIL DAN PEMBAHASAN}

Hasil penelitian menujukkan bahwa bentuk kata sapaan kekerabatan bahasa Aceh itu bervasiasi disebebkan oleh hubungan yang dimiliki penyapa dengan orang yang disapa. Selain itu, kevariasian bentuk-bentuk dan penggunaan kata sapaan kekerabatan bahasa Aceh disebabkan oleh faktor yang mempengaruhinya. Berdasarkan penelitian tersebut ditemukan bahwa bentuk kata sapaan kekerabatan bahasa Aceh terdiri atas kata sapaan berdasarkan berdasarkan garis keturunan dan kata sapaan berdasarkan hubungan perkawinan.

\section{1) Kata sapaan berdasarkan garis keturunan}

Kata sapaan kekerabatan berdasarkan garis keturunan adalah kata sapaan yang digunakan untuk memanggil, menyapa, dan menyebut lawan bicara yang memiliki hubungan kekerabatan disebabkan oleh keturunan atau pertalian darah. Sapaan kekerabatan berdasarkan garis keturunan digunakan untuk menyapa anggota kerabat yang mempunyai hubungan langsung atau pertalian darah dengan penyapa (ego). Anggota keluarga yang dimaksud adalah keluarga inti dan keluarga luas. Kata sapaan kekerabatan berdasarkan garis keturunan yang terdapat di Kabupaten Aceh Utara pada dua daerah kecamatan penelitian, yaitu Kecamatan Samudera dan Kecamatan Meurah Mulia dapat dilihat pada tabel berikut ini.

Tabel 1. Sapaan Kekerabatan Bahasa Aceh berdasarkan Garis Keturunan dalam Tuturan Masyarakat Kabupeten Aceh Utara

\begin{tabular}{||l|l|l|}
\hline \hline No. & $\begin{array}{l}\text { Pengguaan } \\
\text { Sapaan }\end{array}$ & Bentuk Kata Sapaan \\
\hline \hline 1 & $\begin{array}{l}\text { ayah } \\
\text { kandung }\end{array}$ & ayah, abu, abi, wallet \\
\hline 2 & $\begin{array}{l}\text { kakak laki- } \\
\text { laki ayah }\end{array}$ & abuwa, yahwa, pakwa \\
\hline 3 & $\begin{array}{l}\text { kakak } \\
\text { perempuan } \\
\text { ayah }\end{array}$ & mawa/wa, miwa \\
\hline
\end{tabular}




\begin{tabular}{||l|l|l|}
\hline No. & $\begin{array}{l}\text { Pengguaan } \\
\text { Sapaan }\end{array}$ & Bentuk Kata Sapaan \\
\hline \hline 4 & $\begin{array}{l}\text { adik laki- } \\
\text { laki ayah }\end{array}$ & $\begin{array}{l}\text { apacut, apa + nama } \\
\text { diri, yah bit, cék }\end{array}$ \\
\hline 5 & $\begin{array}{l}\text { adik } \\
\text { perempuan } \\
\text { ayah }\end{array}$ & $\begin{array}{l}\text { mabit, macék/makcék, } \\
\text { téh cut }\end{array}$ \\
\hline 6 & $\begin{array}{l}\text { ayah dari } \\
\text { ayah }\end{array}$ & $\begin{array}{l}\text { nèk, ayah/yah syik, abu } \\
\text { syik, ampôn nèk }\end{array}$ \\
\hline 7 & $\begin{array}{l}\text { ibu dari } \\
\text { ayah }\end{array}$ & nèk, masyik, ma tuha \\
\hline 8 & $\begin{array}{l}\text { ayah dari } \\
\text { kakek }\end{array}$ & Nèktu \\
\hline 9 & $\begin{array}{l}\text { ibu dari } \\
\text { kakek }\end{array}$ & nèktu, masyiktu \\
\hline 10 & $\begin{array}{l}\text { kakak } \\
\text { perempuan }\end{array}$ & $\begin{array}{l}\text { cuda, kakak/kak, } \\
\text { cupo/cut po, a }\end{array}$ \\
\hline 11 & $\begin{array}{l}\text { kakak laki- } \\
\text { laki }\end{array}$ & $\begin{array}{l}\text { abang/bang, aduen, } \\
\text { bang + nama diri }\end{array}$ \\
\hline 12 & $\begin{array}{l}\text { adik } \\
\text { perempuan }\end{array}$ & $\begin{array}{l}\text { adoe, adék/dék, dék + } \\
\text { nama diri }\end{array}$ \\
\hline 13 & $\begin{array}{l}\text { adik laki- } \\
\text { laki }\end{array}$ & adoe, adék/dék, nama \\
\hline 14 & anak & aneuk/neuk, nyak \\
\hline 15 & $\begin{array}{l}\text { anak laki- } \\
\text { laki }\end{array}$ & $\begin{array}{l}\text { aneuk agam, si agam, } \\
\text { nama }\end{array}$ \\
\hline 16 & $\begin{array}{l}\text { anak } \\
\text { perempuan }\end{array}$ & aneuk inöng, si dara, \\
\hline 17 & Cucu & Cuco \\
\hline 18 & $\begin{array}{l}\text { adik laki- } \\
\text { laki kakek }\end{array}$ & nèk, yah syik/abu syik \\
\hline 19 & $\begin{array}{l}\text { adik } \\
\text { perempuan } \\
\text { kakek }\end{array}$ & nèk, masyik \\
\hline 20 & $\begin{array}{l}\text { kakak laki- } \\
\text { laki kakek }\end{array}$ & nèk, yah syik/abu syik \\
\hline 21 & $\begin{array}{l}\text { kakak } \\
\text { kakek }\end{array}$ & nèk, masyik \\
\hline
\end{tabular}

\section{2) Kata sapaan berdasarkan hubungan perkawinan}

Sapaan kekerabatan berdasarkan hubungan perkawinan disebabkan oleh pertalian tidak langsung yang terjadi karena adanya perkawinan. Data tentang bentuk sapaan kekerabatan bahasa Aceh berdasarkan garis perkawinan atau hubungan tidak langsung dalam tuturan masyarakat Kabupaten Aceh Utara tersaji dalam tabel korpus data berikut ini.
Tabel 2. Sapaan Kekerabatan Bahasa Aceh berdasarkan Hubungan Perkawinan dalam Tuturan Masyarakat Kabupeten Aceh Utara

\begin{tabular}{|c|c|c|}
\hline No. & $\begin{array}{l}\text { Pengguaan } \\
\text { Sapaan } \\
\end{array}$ & $\begin{array}{l}\text { Bentuk Kata } \\
\text { Sapaan } \\
\end{array}$ \\
\hline 1 & ibu kandung & $\begin{array}{l}\text { mak, ummi, poma, } \\
\text { cut nyak }\end{array}$ \\
\hline 2 & $\begin{array}{l}\text { kakak laki- } \\
\text { laki ibu }\end{array}$ & $\begin{array}{l}\text { abuwa, yahwa, } \\
\text { pakwa }\end{array}$ \\
\hline 3 & $\begin{array}{l}\text { kakak } \\
\text { perempuan } \\
\text { ibu }\end{array}$ & mawa/wa, miwa \\
\hline 4 & $\begin{array}{l}\text { adik laki-laki } \\
\text { ibu }\end{array}$ & $\begin{array}{l}\text { apacut, apa + nama } \\
\text { diri, yah bit, cék }\end{array}$ \\
\hline 5 & $\begin{array}{l}\text { adik } \\
\text { perempuan } \\
\text { ibu }\end{array}$ & $\begin{array}{l}\text { mabit, } \\
\text { macék/makcék, téh } \\
\text { cut }\end{array}$ \\
\hline 6 & ibu dari ibu & nèk, masyik, \\
\hline 7 & ayah dari ibu & $\begin{array}{l}\text { nèk, ayah/yah syik, } \\
\text { abu syik }\end{array}$ \\
\hline 8 & $\begin{array}{l}\text { ayah dari } \\
\text { nenek }\end{array}$ & Nèktu \\
\hline 9 & ibu dari nenek & nèktu, masyiktu \\
\hline 10 & $\begin{array}{l}\text { suami kakak } \\
\text { perempuan }\end{array}$ & $\begin{array}{l}\text { tu muda, } \\
\text { abang/bang }\end{array}$ \\
\hline 11 & $\begin{array}{l}\text { istri kakak } \\
\text { laki-laki }\end{array}$ & $\begin{array}{l}\text { tu muda, kak, } \\
\text { macék/makcék }\end{array}$ \\
\hline 12 & suami & $\begin{array}{l}\text { lintô, lakoe, yah } \\
\text { sinyak/yah aneuk } \\
\text { miet, bang }\end{array}$ \\
\hline 13 & istri & $\begin{array}{l}\text { ma si nyak/ma } \\
\text { aneuk miet, } \\
\text { pereumoh, } \\
\text { adék/dék }\end{array}$ \\
\hline 14 & Mertua & $\begin{array}{l}\text { mak tuan dan ayah } \\
\text { tuan }\end{array}$ \\
\hline 15 & $\begin{array}{l}\text { mertua } \\
\text { perempuan }\end{array}$ & mak, cut ma \\
\hline 16 & $\begin{array}{l}\text { mertua laki- } \\
\text { laki }\end{array}$ & ayah, abu \\
\hline 17 & Menantu & Meulintèe \\
\hline 18 & $\begin{array}{l}\text { suami dari } \\
\text { adik } \\
\text { perempuan } \\
\text { ibu }\end{array}$ & $\begin{array}{l}\text { cék, cék + nama } \\
\text { diri }\end{array}$ \\
\hline 19 & $\begin{array}{l}\text { istri dari adik } \\
\text { laki-laki ibu }\end{array}$ & $\begin{array}{l}\text { cék, cék + nama } \\
\text { diri, macék/makcék }\end{array}$ \\
\hline 20 & $\begin{array}{l}\text { suami dari } \\
\text { kakak }\end{array}$ & abuwa, pakwa \\
\hline
\end{tabular}




\begin{tabular}{|c|c|c|}
\hline No. & $\begin{array}{l}\text { Pengguaan } \\
\text { Sapaan }\end{array}$ & $\begin{array}{l}\text { Bentuk Kata } \\
\text { Sapaan }\end{array}$ \\
\hline & $\begin{array}{l}\text { perempuan } \\
\text { ibu }\end{array}$ & \\
\hline 21 & $\begin{array}{l}\text { istri dari } \\
\text { kakak laki- } \\
\text { laki ibu }\end{array}$ & Mawa \\
\hline 22 & ibu tiri & mak, ma ui \\
\hline 23 & ayah tiri & ayah, yah ui \\
\hline 24 & $\begin{array}{l}\text { anak laki-laki } \\
\text { dan } \\
\text { perempuan } \\
\text { dari kakak dan } \\
\text { abang ibu }\end{array}$ & $\begin{array}{l}\text { abang/bang + } \\
\text { nama, kak + nama, } \\
\text { adék/dék, dék + } \\
\text { nama diri. }\end{array}$ \\
\hline
\end{tabular}

\section{PEMBAHASAN}

Hasil penelitian menunjukkan bahwa umumnya sapaan kekerabatan bahasa Aceh berdasarkan garis keturunan dan hubungan perkawinan memiliki banyak persamaan di kedua lokasi penelitian. Dengan kata lain, sapaan yang digunakan tidak jauh berbeda antara pihak laki-laki ataupun pihak perempuan. Oleh karena itu, sapaan yang digunakan dalam keluarga dari pihak ayah (laki-laki) juga digunakan oleh keluarga dari pihak ibu (perempuan). Berikut ini penjelasan mengenai bentuk dan penggunaan sapaan kekerabatan bahasa Aceh, baik berdasarkan garis keturunan maupun hubungan perkawinan dalam tuturan masyarakat Kabupaten Aceh Utara.

Bentuk sapaan yang digunakan untuk menyapa ayah kandung adalah $a y a h, a b u, a b i$, dan walét. Selanjutnya untuk menyapa ibu kandung, penyapa mengunakan sapaan mak, ummi, dan cut nyak. Berikutnya, untuk penyapaan terhadap kakak laki-laki ayah menggunakan sapaan abuwa, yahwa, dan pakwa. Kata sapaan untuk menyapa kakak perempuan ayah adalah mawa/wa, dan miwa. Sapaan ini juga digunakan untuk menyapa kakak perempuan ibu. Penyapa menggunakan sapaan apacut, apa + nama diri, yah bit, yahwa, dan cék untuk menyapa adik laki-laki ayah dan ibu. Untuk menyapa adik perempuan ayah dan ibu, penyapa menggunakan sapaan mabit, macék/makcék, dan téh cut.

Penyapaan terhadap ayah dari ayah dan ayah dari ibu menggunakan nèk, ayah/yah syik, dan abu syik. Sapaan nèk, masyik, dan ma tuha digunakan penyapa untuk menyapa ibu dari ayah dan ibu dari ibu. Kata penyapa untuk menyapa ayah dari kakek ibu dan ayah adalah nèktu. Untuk meyapa ibu dari kakek, penyapa menggunakan sapaan nèktu, dan masyiktu. Kata tu pada sapaan nèktu, dalam bahasa Aceh berarti 'buyut'. Jadi, kata sapaan nèktu digunakan untuk menyapa kakek buyut dari ayah atau ibu.

Penggunaan sapaan cuda, dan kakak/kak digunakan penyapa terhadap kakak perempuan. Selanjutnya, untuk menyapa kakak laki-laki, penyapa menggunakan sapaan abang/bang, aduen, dan bang + nama diri. Untuk menyapa adik laki-laki atau adik perempuan, penyapa menggunakan sapaan adoe, adék/dék, dan nama. Penyapa menggunakan sapaan aneuk/neuk dan nyak untuk menyapa anak, sapaan aneuk agam, si agam, dan nama untuk menyapa anak lakilaki, dan sapaan aneuk inöng, si dara untuk menyapa anak perempuan. Bentuk sapaan kekerabatan bahasa Aceh terhadap cucu adalah cuco. Kemudian, untuk menyapa adik laki-laki kakek penyapa mengunakan sapaan nèk, dan yah syik. Sapaan nèk dan masyik digunakan untuk menyapa adik perempuan dan kakak perempuan kakek. Penyapaan terhadap kakak laki-laki kakek menggunakan sapaan nèk, dan abu syik.

Kata sapaan yang digunakan untuk menyapa ibu adalah mak, poma, ummi dan cut nyak. Penyapa menggugunakan kata sapaan $t u$ muda dan abang/bang untuk menyapa suami kakak perempuan. Penggunaan sapaan tu muda, kak, dan macék/makcék digunakan ego untuk menyapa istri kakak laki-laki. Penyapaan terhadap suami ego menggunakan sapaan abang/bang. Jika sudah memiliki anak, kata sapaan yang digunakan yaitu yah si nyak/yah aneuk miet dan yah/abu+nama anak pertama. Ego menyapa istri dengan sapaan adék/dék. Penggunaan sapaan ma sinyak/ma aneuk miet dan mak + nama anak pertama untuk menyapa istri jika sudah memiliki anak. Kata sapaan lintô dan lakoe digunakan untuk menyebut suami dan penggunaan sapaan pereumoh untuk menyebut istri (pengantin baru) yang belum memiliki anak.

Penyapa menyapa ibu mertua/ibu suami dan ayah mertua/ayah suami dengan sapaan mak tuan dan yah tuan. Tuturan ini tidak dipakai saat bertutur langsung dengan ibu mertua atau ayah mertua, sapaan yang digunakan sama dengan bentuk sapaan kekerabtan bahasa Aceh seperti menyapa ayah 
kandung atau ibu kandung. Penyapaan terhadap suami dari adik perempuan ibu ego menggunakan sapaan cék dan cék + nama diri.Untuk menyapa istri dari adik laki-laki ibu, ego mengunakan sapaan cék, cék + nama diri, dan macék/makcék. Abuwa dan pakwa merupakan penggunaan sapaan oleh ego terhadapa suami dari kakak perempuan ibu. Penggunaan mawa digunakan oleh ego untuk menyapa istri dari kakak laki-laki ibu. Penyapa menggunakan sapaan ma ui dan yah $u i$ untuk menyapa ibu tiri dan ayah tiri. Penggunaan sapaan ini tidak digunakan ketika penyapa (anak laki-laki dan anak perempuan) menyapa ayah tiri/ibu tiri secara langsung dalam sebuah pertuturan.

Kata penyapa abang/bang + nama, kak + nama, adék/dék, dan dék + nama diri digunakan penyapa untuk menyapa anak lakilaki/anak perempuan dari kakak dan abang ibu. Bentuk sapaan ini berbeda-beda menurut usia dan jenis kelamin yang dimiliki oleh pesapa. Bentuk kata sapaan abang/bang + nama, kak + nama digunakan untuk menyapa orang yang lebih tua dari penyapa. Penggunaan sapaan adék/dék dan dék + nama diri terhadap anak laki-laki/anak perempuan dari kakak/abang ibu yang usianya lebih muda dari penyapa.

\section{PENUTUP}

Bentuk kata sapaan kekerabatan bahasa Aceh dalam tuturan masyarakat Kabupaten Aceh Utara terdiri atas (1) bentuk kata sapaan kekerabatan berdasarkan garis keturunan dan (2) bentuk kata sapaan berdasarkan hubungan perkawinan. Data berupa kata sapaan berdasarkan garis keturunan sebanyak 21 penggunaan dengan bentuk kata sapaan di antaranya adalah ayah, $a b u, a b i$, walét, dan abuwa. Selanjutnya, kata sapaan kekerabatan bahasa Aceh berdasarkan hubungan perkawinan diperoleh sebanyak 24 penggunaan dengan bentuk kata sapaan di antaranya adalah mak, ummi, poma, cut nyak, abuwa, dan yahwa. Penggunaan sapaan kekerabatan berdasarkan keturunan adalah penggunaan kata sapaan seperti terhadap ayah kandung, kakak laki-laki ayah, kakak perempuan ayah dan adik perempuan ayah. Berikutnya, penggunaan sapaan kekerabatan berdasarkan hubungan perkawinan adalah penggunaan kata sapaan seperti terhadap ibu kandung, kakak laki-laki ibu, suami, istri, mertua dan menantu.

Berdasarkan simpulan di atas, saran yang dapat diberikan oleh penulis adalah sebagai berikut. Bagi Pemda disarankan untuk melakukan sosialisasi kepada masyarakat mengenai bentuk kata sapaan dan penggunaan sapaan kekerabatan bahasa Aceh. Bagi dunia pendidikan disarankan kepada setiap guru yang mengajarkan bahasa daerah untuk memperkenalkan bentuk dan penggunaan kata sapaan kekerabatan bahasa Aceh. Selain itu, para pendidik juga dapat melakukan seminar umum/khusus mengenai bentuk dan penggunaan sapaan kekerabatan bahasa Aceh. Bagi masyarakat disarankan untuk selalu menggunakan kata sapaan kekerabatan bahasa Aceh supaya bentuk dan penggunaan tersebut tetap terjaga kelestariannya.

\section{DAFTAR PUSTAKA}

Depdikmas. (2016). Kamus Besar Bahasa Indonesia (edisi 5). Jakarta: Balai Pustaka.

Irawan, Windo Dicky. (2019). "Kata Sapaan Kekerabatan dalam Masyarakat Lampung Sungkai”. Jurnal Elsa, Volume 17, Nomor 1, April 2019. (http://jurnal.umko.ac.id/index.pp/e lsa/article/viuw/109)

Jannah, Miftahul. (2019). Sapaan Kekerabatan dalam Tuturan Masyrakat Kabupaten Batu Bara Provinsi Sumatera Utara". Jurnal Bahasa dan Sastra, Volume 13 No. 2, Juli 2019:143-158.

Mahsun. (2017). Metode Penelitian Bahasa: Tahapan, Strategi, Metode, dan Tekniknya Ed-3. Depok: Rajawali Pers.

Muhammad. (2014). Metode Penelitian Bahasa. Jogyakarta: Ar-Ruzz Media.

Relawati, Miranti. (2012). "Penggunaan Ragam Sapaan yang Digunakan Anak Kost Desa Pabelan Kartasura Sukoharjo." Skripsi tidak diterbitkan. Surakarta: Universitas Muhammadiyah Surakarta. 
Rusbiyantoro, Wenni. (2011). "Penggunaan Kata Sapaan dalam Bahasa Melayu Kutai". Journal Parole Volume 2, No. $\quad 1, \quad$ April 2011. (http://www.lontar.ui.ac.id/file:file= digital/12345-121301A294kkata\%20sapaan-leteratur.pdf)

Saleh, R. (2017). "Bentuk Sapaan Kekerabatan dalam Bahasa Banjar di Tembilahan, Riau". Jurnal bahasa dan sastra-Madah, Volume 8, Nomor 1, April 2017:19-32. (https://madah.kemendikbud.go.id/i ndex.php/madah/article/view/74)

Sari, Nika. dkk. (2013). "Sistem Kata Sapaan Kekerabatan dalam Bahasa Melayu di Kepenghuluan Bangko Kiri Kecamatan Bangko Pusako Kabupayen Rokan Hilir Provinsi Riau". Jurnal Pendidikan Bahasa dan Sastra Indonesia. Volume 1. No. 2 Maret 2013. Seri G477-562. (http://media,neliti.com/media/publ icatian/118981-ID-sistem-katasapaan-kekerabatan-dalam-bah-pdf)

Saputra, Sabar dan Sainil Amral. (2020). "Kata Sapaan Kekerabatan Bahasa Melayu Jambi di Desa Teriti Kecamatan Sumay Kabupaten Tebo". Jurnal Ilmiah Pendidikan Bahasa dan Satra Indonesia, Volume. 4, No.1, April 2020. (http://Aksara.umbari.ac.id/index.p hp/aksara)

Subhayni, dkk. (2020). "Restrukturisasi Sapaan Kekerabatan Bahasa Aceh Sebagai Pendidikan Strategi Tutur Sapa Bagi Kaum Muda Aceh." Jurnal Serambi Ilmu, Volume 21, No.1, Maret 2020. (http://jurnal.serambimekkah.ac.id/s erambi-ilmu/article/view/1901) 